\title{
Can greater muscularity in larger individuals resolve the $3 / 4$ power-law controversy when modelling maximum oxygen uptake?
}

\author{
A. M. Nevill*, G. Markovic $\dagger$, V. Vucetic $\dagger$ and R. Holder $\ddagger$ \\ * Research Institute of Health Sciences, University of Wolverhampton, Walsall, UK \\ $\dagger$ Faculty of Kinesiology, University of Zagreb, Zagreb, Croatia \\ $\ddagger$ School of Mathematics and Statistics, University of Birmingham, UK \\ Received 15 January 2004; in revised form 20 April 2004; accepted 10 May 2004
}

\begin{abstract}
Summary. Background: The power function relationship, $\mathrm{MR}=a \cdot m^{b}$, between metabolic rate (MR) and body mass $m$ has been the source of much controversy amongst biologists for many years. Various studies have reported mass exponents $(b)$ greater than the anticipated 'surface-area' exponent 0.67 , often closer to 0.75 originally identified by Kleiber.

Aim: The study aimed to provide a biological explanation for these 'inflated' exponents when modelling maximum oxygen uptake $\left(\mathrm{VO}_{2} \max \right)$, based on the observations from this and previous studies that larger individuals develop disproportionately more muscle mass in the arms and legs.

Research design and subjects: A cross-sectional study of 119 professional soccer players from Croatia aged 18-34 was carried out.

Results: Here we confirm that the power function relationship between $\dot{\mathrm{VO}}_{2}$ max and body mass of the professional soccer players results in an 'inflated' mass exponent of 0.75 (95\% confidence interval from 0.56 to 0.93 ), but also the larger soccer players have disproportionately greater leg muscle girths. When the analysis was repeated incorporating the calf and thigh muscle girths rather than body mass as predictor variables, the analysis not only explained significantly more of the variance in $\mathrm{VO}_{2} \mathrm{max}$, but the sum of the exponents confirmed a surface-area law.

Conclusions: These findings confirm the pitfalls of fitting body-mass power laws and suggest using muscle-girth methodology as a more appropriate way to scale or normalize metabolic variables such as $\dot{\mathrm{VO}}_{2}$ max for individuals of different body sizes.
\end{abstract}

\section{Introduction}

An enduring mystery that has challenged biologists and physiologists alike for over a century is how metabolic rate (MR) is related to body size (see Voit 1901, cited by Kleiber 1987, p. 182). Larger mammals expend more energy than smaller mammals due to the greater energy cost of metabolism and locomotion. However, if energy expenditure is expressed as a simple ratio standard, per unit body mass, smaller mammals consume more energy per unit body mass than larger mammals. A theoretical explanation for these observations is based on the assumption that energy expenditure obeys the surface-area law (Schmidt-Nielsen 1984, Weibel 2002).

Assuming that mammals are geometrically similar to each other, individual body components (e.g. homologous muscles, hearts, lungs) should have masses proportional to body mass $(m)$, cross-sectional or surface areas proportional to $m^{0.67}$ and linear dimensions $(L)$, such as heights or limb girths, proportional to $L=m^{0.33}$. Under such circumstances, if energy expenditure obeys the surface-area law, then MR should be proportional to $m^{0.67}$ (or $L^{2}$ ). 
Similarly, maximum metabolic rate (MMR) or maximum oxygen uptake $\left(\dot{\mathrm{VO}}_{2} \max \right)$ in humans should also theoretically be proportional to $L^{2}$ or $m^{0.66}$ (Astrand and Rodahl 1986). However, a large number of studies investigating the relationship between MR (either basal or maximal) and body mass, both human and animal, have reported mass exponents greater than 0.67 , often closer to the parameter, 0.75, originally proposed by Kleiber (1932). Since then, numerous authors have attempted to explain these inflated exponents using a variety of different theories including the model of elastic similarity proposed by McMahon (1973) and more recently the fractal network model adopted by West et al. (1999). Interestingly, the model proposed by West and co-workers questioned the concept of geometric similarity assumed by the 2/3-power law by observing that organisms evolve hierarchical branching networks that terminate in size-invariant, rather than size-proportional units, e.g. capillaries and mitochondria.

A recent article by Darveau et al. (2002) has provided a new insight into this conundrum. Rather than expressing the relationship between MR and body mass as a single power function model $\mathrm{MR}=a \cdot m^{b}$, where $a$ and $b$ are referred to as the scaling constant and scaling exponent, respectively, an alternative weighted sum of power functions is proposed, each estimated from a range of control sites or processes (e.g. pulmonary diffusion, cardiac output, ATP synthesis for muscle work) all known to contribute to metabolic pathways.

However, all the mass exponents adopted by Darveau et al. (2002) in their calculations (simulations) were still greater than 0.67. For example, the mass exponents used to estimate maximum metabolic rate (MMR) ranged from $b=0.77$ (actomyosin ATPase) to $b=1.08$ (pulmonary diffusion). As far as we could ascertain, Darveau and co-workers made no attempt to provide a biological explanation as to why any of these mass exponents were all greater than 0.67 , either individually or collectively. Interestingly, Darveau et al.'s observations on relationship between MMR and body mass were all based on human maximum oxygen uptake $\left(\mathrm{V}_{2} \max \right)$ performance.

More recently, White and Seymour (2003) added to the debate when modelling the relationship between basal metabolic rate (BMR) and body mass of mammals. By introducing body temperature, digestive state and phylogeny into their analysis, the authors were able to confirm that BMR was proportional to $m^{0.67}$. However, because their explanation only involved modelling basal metabolic rate and incorporated factors that differed between species (temperature and digestive states), their explanation is neither appropriate nor valid to explain the inflated exponents observed when investigating the relationship between $\mathrm{MMR}$ or $\dot{\mathrm{VO}}_{2}$ max and body mass in humans (within a species).

A explanation for the inflated $\mathrm{VO}_{2}$ max-mass exponents in humans was proposed by Nevill et al. (2004), who observed that human adult physiques are not geometrically similar to each other. In both athletic and non-exercising controls, body circumferences/limb girths develop at a greater rate than that anticipated by geometric similarity in fleshy sites, containing both muscle and fat (upper arms and legs), and less than anticipated in bony sites (head, wrists and ankles). The authors also estimated that the muscle masses in the arms, thighs and calves of athletes and non-exercising controls increase at a greater rate than that predicted by geometric similarity, i.e. the muscle masses of the arms, thighs and calves demonstrate a disproportionate enlargement with bigger individuals. Given that the leg muscle mass makes a major contribution to $\dot{\mathrm{VO}}_{2}$ max performance, the authors go on to speculate that the non-exercising controls will expend a similar disproportionate 
increase in maximum oxygen uptake $\left(\dot{\mathrm{VO}}_{2} \max \right)$, similar to the mass exponent $b=0.75$, proposed by Kleiber (1932) and Nevill (1994).

Further support for the theory that muscular enlargement might help to explain the inflated mass exponents when modelling $\mathrm{V}_{2}$ max, comes from a recent article (Nevill et al. 2003). The authors report estimated calf and thigh leg muscle masses of 106 men and 30 women from 11 sports, to increase in proportion to body mass, $m^{1.11}$ and $m^{1.38}$, respectively. The authors also observe an inflated body mass exponent of $b=0.94$ when modelling the $\mathrm{VO}_{2}$ max of 174 international standard men and women athletes. Unfortunately, a serious limitation of this study, acknowledged by the authors, was that both these observations were based on data from two independent or mutually exclusive studies.

Hence, the purpose of the present study was to explore whether (a) we can detect evidence of both a muscular enlargement of the legs and an inflated mass exponent when modelling $\dot{\mathrm{VO}}_{2}$ max in the same group of subjects, and (b) by adopting muscle girth measurements as more appropriate body size scaling variables, $\dot{\mathrm{V}}_{2}$ max does indeed obey a true surface-area (or cross-section) law.

\section{Methods}

\subsection{Subjects}

Subjects $(n=119)$ were Croatian First Division (the top division in Croatia) male soccer players aged 18-34 (mean age 22.1 \pm 3.8 years) (mean \pm SD), most of whom were included in the Croatian Olympic Association programme that monitors the health and training status of athletes. Subjects provided written informed consent for the study which was approved by University of Zagreb's Faculty of Kinesiology Ethics Committee. Forty-two of the soccer players were members of one of three most successful soccer teams in Croatia, and seven of them were members of the Croatian National Team at the time of testing. Physical characteristics of the subjects by playing position are given in table 1 .

\subsection{Procedures}

Laboratory assessments were undertaken at the Faculty of Kinesiology, University of Zagreb, Croatia. Anthropometric measures were made according to procedures recommended by the International Biological Program (Weiner and Lourie 1969). Each athlete was measured by two experienced anthropometrists prior to the measurement of $\dot{\mathrm{VO}}_{2}$ max. Body mass was assessed to the nearest $0.1 \mathrm{~kg}$ using beam balance scale with the athletes wearing minimal clothing. Body height

Table 1. Physical characteristics and the estimated calf and thigh muscle girths (means and standard deviations) of the Croatian soccer players by playing position.

\begin{tabular}{|c|c|c|c|c|c|c|c|c|c|c|c|}
\hline \multirow[b]{2}{*}{ Position } & \multirow[b]{2}{*}{$n$} & \multicolumn{2}{|c|}{ Age } & \multicolumn{2}{|c|}{ Height** } & \multicolumn{2}{|c|}{ Mass** } & \multicolumn{2}{|c|}{$\begin{array}{l}\text { Corrected } \\
\text { calf }(\mathrm{cm})^{*}\end{array}$} & \multicolumn{2}{|c|}{$\begin{array}{l}\text { Corrected } \\
\text { thigh }(\mathrm{cm})^{* *}\end{array}$} \\
\hline & & Mean & SD & Mean & SD & Mean & SD & Mean & SD & Mean & SD \\
\hline Goalkeeper & 4 & 23.5 & 3.3 & 189.4 & 5.0 & 87.3 & 9.8 & 38.5 & 2.9 & 57.5 & 2.5 \\
\hline Defence & 33 & 22.1 & 4.1 & 182.4 & 5.3 & 78.9 & 6.8 & 36.8 & 2.2 & 55.7 & 2.6 \\
\hline Midfield & 64 & 22.0 & 3.7 & 179.8 & 6.7 & 75.3 & 6.1 & 35.8 & 1.8 & 54.5 & 2.2 \\
\hline Forward & 18 & 22.1 & 3.5 & 179.5 & 3.3 & 77.3 & 3.8 & 36.6 & 1.7 & 55.9 & 1.9 \\
\hline Total/mean & 119 & 22.1 & 3.8 & 180.8 & 6.2 & 77.0 & 6.6 & 36.2 & 2.0 & 55.4 & 2.4 \\
\hline
\end{tabular}

${ }^{*} p<0.05 ;{ }^{* *} p<0.01$. 
was assessed to the nearest $0.1 \mathrm{~cm}$ using fixed stadiometer. The stadiometer and scale were calibrated periodically during the study. Girth circumferences were measured using an anthropometric tape to $0.1 \mathrm{~cm}$ at the thigh (midway between the inguinal crease and proximal border of patella) and the maximum calf on the left side of the body. Skinfolds were measured to $0.1 \mathrm{~mm}$ on the left side of the body using Harpenden caliper (Quinton Instruments, Seattle, WA, USA) along the circumferences at anterior thigh and medial calf.

The calculation of corrected girths (to estimate the subjects' thigh and calf muscle girths) used the principal assumptions outlined in Stewart et al. (2002). In brief, tissue boundaries were assumed to be circular and concentric. If the skin plus adipose tissue thickness is $d$, and the thigh or calf girth is $G$, then the corrected muscle girth (MG) is estimated by $\mathrm{MG}=G-2 \cdot \pi \cdot d$ (skinfold values are converted to centimetres for this calculation). If it is further assumed that the skinfold caliper reading $S$ is twice the adipose tissue thickness, then $\mathrm{MG}=G-\pi \cdot S$.

Maximal oxygen uptake ( $\left.\dot{\mathrm{VO}}_{2} \max \right)$ was determined during the continuous incremental tests to volitional exhaustion on motorized treadmill. The treadmill test began with 3 min of walking at $3 \mathrm{~km} \mathrm{~h}^{-1}$, and then speed was increased by $1 \mathrm{~km} \mathrm{~h}^{-1}$ every minute until voluntary exhaustion. Inclination was constant at $1.5^{\circ}$. Expired air was collected and analysed by on-line breath-by-breath gas exchange system (COSMED, Quark $b^{2}$, Rome, Italy), that was calibrated before each test using gases of known concentrations. Heart rate (HR) was monitored with a Polar Vantage XL (Kempele, Finland) telemetric heart rate monitor. End-of-test criteria included two of the following: (1) volitional exhaustion, (2) achieving a plateau in $\mathrm{VO}_{2}$ (highest values were calculated as arithmetic means of the two consecutive highest $30 \mathrm{~s}$ values), and (3) $\mathrm{HR} \geq 90 \%$ of age-predicted maximum.

\subsection{Statistical methods}

In order to establish whether calf and/or thigh muscle girths (MG) increase in proportion to body mass $(\mathrm{kg})$, the following allometric model was fitted:

$$
\mathrm{MG}=a_{i} \operatorname{mass}^{k_{1}},
$$

where $a_{i}$ is the scaling constant and $k_{1}$ is the mass exponent. The model can be linearized with a $\log$ transformation, and an analysis of covariance (ANCOVA) used to compare muscle girth by 'playing position' having controlled for differences in body mass, i.e. by allowing $a_{i}$ to vary for each playing position using body mass as the covariate. As stated above, if soccer players are geometrically similar to each other, i.e. assuming subjects' bodies are the same shape, but their body size dimensions vary/increase in proportion to each other, both the calf and thigh muscle girths should increase in proportion to $m^{0.33}$, where $m$ denotes the subjects' body mass.

Provided that subjects' muscle masses are geometrically similar to each other, differences in maximum oxygen uptake between playing position can be compared using an ANCOVA with body mass as the covariate, i.e. body mass will reflect the correct (and unbiased) proportion of muscle mass associated with $\dot{\mathrm{VO}}_{2}$ max. The adopted ANCOVA model for maximum oxygen uptake $\left(\mathrm{V}_{2} \max \right)$, based on the proportional allometric model originally proposed by Nevill and Holder (1994), is given as

$$
\dot{\mathrm{VO}}{ }_{2} \max =m^{k_{2}} \cdot \exp \left(b_{0}+b_{1} \cdot \operatorname{age}+b_{2} \cdot \mathrm{age}^{2}\right),
$$


where $k_{2}$ is the scaling body mass exponent. As stated above, assuming $\mathrm{V}_{2} \max$ obeys the surface area law $\left(L^{2}\right)$, the mass exponent should be approximately $m^{0.67}$. Age was incorporated into the model as a quadratic polynomial (incorporating both an age and age ${ }^{2}$ term) to accommodate the likelihood that $\dot{\mathrm{VO}}_{2}$ max will peak sometime during adulthood.

The model can be linearized with a log-transformation, and ANCOVA can then be used to estimate the effects of playing position having controlled for differences in these confounding covariates of mass, age, and age ${ }^{2}$. The transformed ANCOVA model becomes

$$
\log _{\mathrm{e}}\left(\dot{\mathrm{VO}}_{2} \max \right)=k_{2} \cdot \log _{\mathrm{e}}(m)+b_{0}+b_{1} \cdot \operatorname{age}+b_{2} \cdot \operatorname{age}^{2},
$$

where the constant $b_{0}$ is allowed to vary for each level of playing position. If the ANCOVA main effect difference between positions is detected, pairwise comparisons were made using the Bonferroni adjustment for multiple comparisons.

If on the other hand, we find that subjects' muscle masses are not geometrically similar to each other, we need to adopt an alternative covariate or covariates that will reflect both the subjects' body size, but also the muscular enlargement observed in the leg muscle girth measurements (equation 1), especially given that leg muscles contribute disproportionately to $\dot{\mathrm{VO}}_{2} \max$ in humans (see Hoppeler 1990). Under these circumstances, we propose using stature, calf muscle girth $\left(\mathrm{MG}_{\mathrm{c}}\right)$ and thigh muscle girth $\left(\mathrm{MG}_{\mathrm{t}}\right)$ as alternative covariates in the ANCOVA model for maximum oxygen uptake $\left(\dot{\mathrm{VO}}_{2} \max \right)$ as follows

$$
\dot{\mathrm{VO}}{ }_{2} \max =\text { stature }^{k_{3}} \cdot \mathrm{MG}_{\mathrm{c}}{ }^{k_{4}} \cdot \mathrm{MG}_{\mathrm{t}}{ }^{k_{5}} \cdot \exp \left(b_{0}+b_{1} \cdot \text { age }+b_{2} \cdot \mathrm{age}^{2}\right),
$$

where $k_{3}, k_{4}$ and $k_{5}$ are the exponents for stature, corrected calf and thigh muscle girths, respectively. Given that these three measurements are all linear dimensions of body size $(L)$ and assuming $\dot{\mathrm{VO}}_{2}$ max obeys the surface area law $\left(L^{2}\right)$, the three exponents should sum $\left(k_{3}+k_{4}+k_{5}\right)$ to approximately 2 .

\section{Results}

A one-way ANOVA identified significant differences between playing positions in corrected calf $(p<0.05)$ and corrected thigh $(p<0.01)$ muscle girths (see table 1$)$. However, given that bigger soccer players have greater muscle girths, as soon as body mass was introduced as the covariate using model (equation 1), the ANCOVA of calf and thigh muscle girths failed to identify significant differences between playing position. The fitted body mass exponents (equation 1) for the calf was $k_{1}=0.43(95 \%$ confidence interval from 0.36 to 0.52$)$ and for the thigh was $k_{1}=0.39(95 \%$ confidence interval from 0.33 to 0.45$)$. Note that the confidence interval of the mass exponent for the calf muscle girth exceeds the theoretical value 0.33 , but the confidence interval of the mass exponent for the thigh muscle girth just encompasses the theoretical value 0.33 , predicted by geometric similarity.

This evidence of a greater muscle enlargement in larger soccer players confirms the danger of using body mass as the sole body size covariate to scale $\dot{\mathrm{VO}}_{2} \max$ of individuals of different body size. Given that leg muscle mass makes a major contribution to $\dot{\mathrm{VO}}_{2}$ max (under MMR conditions, $90 \%$ of oxygen consumption is directed towards ATP synthesis for muscle work, Weibel 2000), the observed disproportionate increase in leg muscle mass will inevitability lead to biased and inflated body mass exponents when modelling $\dot{\mathrm{VO}}_{2}$ max. Nevertheless, recognizing 


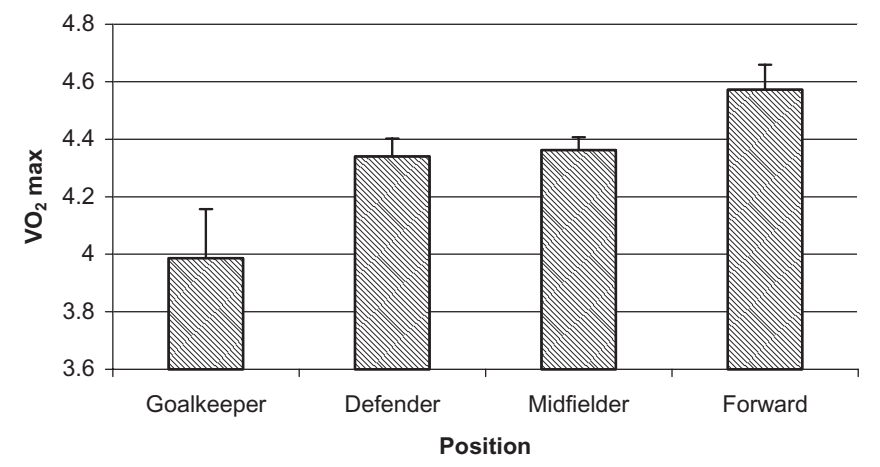

Figure 1. The mean $( \pm \mathrm{SE})$ adjusted $\dot{\mathrm{VO}}_{2} \max$ by position $(p<0.05)$, adjusted about body mass $=76.7 \mathrm{~kg}$ and age 22.1 years $( \pm \mathrm{SE}=$ standard error of estimate $)$.

that the body mass exponent will be unreliable and biased, we fitted the ANCOVA model for $\dot{\mathrm{VO}}_{2} \max$ (equation 2) predominantly for comparative purposes.

The ANCOVA of $\log _{\mathrm{e}}\left(\dot{\mathrm{VO}}_{2} \max \right)$ (equation 3 ) confirmed a significant 'position' main effect. The means and standard error of estimates $( \pm \mathrm{SE})$ for the adjusted $\dot{\mathrm{VO}}_{2}$ max by position are given in figure 1 .

The Bonferroni pairwise comparisons of the adjusted $\dot{\mathrm{V}}_{2}$ max identified forwards as having significantly greater $\dot{\mathrm{VO}}_{2}$ max than goalkeepers, with all other comparisons not significant. The ANCOVA of log-transformed $\dot{\mathrm{VO}}_{2}$ max identified $\log _{\mathrm{e}}$ (mass), age, and age ${ }^{2}$ as all significant covariates. The body mass exponent was estimated as $k_{2}=0.75$ (95\% confidence interval from 0.56 to 0.93$)$. Note that if we wish to express the body mass exponent 0.75 as a 'dimensionally correct' exponent of a linear dimension of body size $(L)$, we would anticipate the exponent to be $3 \times 0.75=2.25$. The age and age $^{2}$ slope parameters were $b=0.047$ and $b_{2}=-0.00095$, respectively. Elementary differential calculus estimated $\dot{\mathrm{V}}_{2} \max$ to peak at age $=-b_{1} /\left(2 \cdot b_{2}\right)=0.047 / 0.0019=24.7$ years. The log-transformed ANCOVA model incorporating body mass as the only body size covariate explained $44 \%$ of the variance in $\dot{\mathrm{VO}}_{2} \max \left(R^{2}=0.438\right.$, adjusted $\left.R^{2}=0.408\right)$.

The ANCOVA model incorporating stature, corrected calf and thigh muscle girth as covariates (replacing the body mass covariate) also identified a significant main effect due to position, with forwards as having significantly greater $\mathrm{V}_{2}$ max than goalkeepers and all other comparisons not significant. The model also identified $\log _{\mathrm{e}}$ (stature), $\log _{\mathrm{e}}\left(\mathrm{MG}_{\mathrm{c}}\right)$ and $\log _{\mathrm{e}}\left(\mathrm{MG}_{\mathrm{t}}\right)$ as significant covariates $(p<0.001)$, with age and age $^{2}$ as marginally significant $(p=0.05$ and $p=0.07$, respectively). The stature exponent was estimated as $k_{3}=0.90$ (95\% confidence interval from 0.44 to 1.36$)$, the calf girth exponent as $k_{4}=0.53$ (95\% confidence interval from 0.21 to $0.85)$ and the thigh girth exponent as $k_{5}=0.63(95 \%$ confidence interval from 0.21 to 1.05$)$. Note that the sum of the exponents $\left(k_{3}+k_{4}+k_{5}\right)$ is $2.06(95 \%$ confidence interval from 1.58 to 2.54 ), close to the anticipated surface-area law exponent 2 . The log-transformed ANCOVA model incorporating stature, corrected calf and thigh muscle girths significantly increased the explained variance in $\dot{\mathrm{VO}}_{2} \max$ $\left(F_{3,109}=3.85, p=0.012\right)$ to $49 \%\left(R^{2}=0.487\right.$, adjusted $\left.R^{2}=0.449\right)$. Indeed, with these three additional covariates, the term $\log _{\mathrm{e}}(m)$ no longer made a significant contribution to the ANCOVA model $(P=0.297)$. 


\section{Discussion}

The assumption that muscular enlargement exists in professional soccer players was confirmed. The fitted mass exponents for the calf and thigh muscle girths were 0.43 and 0.39 , respectively, providing strong evidence that leg muscle mass increase at a greater rate than that predicted by geometric similarity $(0.33)$. These inflated exponents are not dissimilar to the exponents reported by Nevill et al. (2003), although in the present sample of professional soccer players, the calf would appear to enlarging at a greater rate than the thigh, in contrast to the more general athletic population reported by Nevill et al. (2003) where the estimated thigh muscle girth exponent was 0.46 , greater than the calf muscle girth exponent 0.37. Clearly, the leg muscle mass demonstrates a disproportionate enlargement with larger individuals.

Given this evidence of a disproportionate enlargement in leg muscle mass with larger individuals and that under maximum conditions, $90 \%$ of oxygen consumption is directed towards ATP synthesis for muscle work (Weibel 2000, Hochachka and Somero 2002), adopting body mass $(m)$ as the only body-size normalizing variable to model $\dot{\mathrm{VO}}_{2}$ max will inevitably lead to biased and inflated exponents. To demonstrate this, but mainly for comparative purposes, we fitted the proportional allometric ANCOVA model (equation 2) containing body mass and the quadratic age terms. As anticipated, the body mass exponent was greater than 0.67 that assumes a surface-area law association with body mass, and remarkably identical to $k_{2}=0.75$, the mass exponent originally proposed by Kleiber (1932). Based on the fitted age quadratic parameters, we were able to estimate that $\dot{\mathrm{VO}}_{2}$ max of the Croatian soccer players peaks at approximately 25 years, 5 years earlier than the elite athletes reported in Nevill et al. (2003). This difference in peak $\dot{\mathrm{VO}}_{2}$ max was not too surprising given that the elite athletes reported by Nevill et al. (2003) contained of a number of 'veteran' rowers and long distance runners.

The ANCOVA model incorporating the more 'muscular sensitive' covariates of calf and thigh muscle girths explained significantly more variance in $\dot{\mathrm{VO}}_{2} \max$ (49\%) compared with the ANCOVA model adopting body mass as the only bodysize covariate $(44 \%)$. Indeed, all three covariates, $\log _{e}($ stature $), \log _{e}\left(M_{\mathrm{c}}\right)$ and $\log _{\mathrm{e}}\left(\mathrm{MG}_{\mathrm{t}}\right)$, made significant contributions to the ANCOVA model to predict $\dot{\mathrm{VO}}_{2} \max \left(\right.$ all $p<0.001$ ), leaving $\log _{\mathrm{e}}(m)$ as redundant to the model. However, the most enlightening observation from this analysis was that the sum of the three linear covariates' exponents used to predict $\dot{\mathrm{VO}}_{2}$ max was 2.06 , much closer to the anticipated surface-area law exponent 2. Note that we are interpreting the contributions of these three covariates in a similar way to that adopted by DuBois and DuBois (1916) when estimating the surface area of human beings. DuBois and DuBois's formula to estimate body surface area is given by $\mathrm{BSA}=71.84 W^{0.425} \cdot L^{0.725}$, where BSA is the body surface area $\left(\mathrm{cm}^{2}\right), W$ is body mass $(\mathrm{kg})$ and $L$ is stature (cm). Assuming that $W \sim L^{3}$, we can confirm that the formula is 'dimensionally correct' since $W^{0.425} \cdot L^{0.725} \sim\left(L^{3}\right)^{0.425} \cdot L^{0.725}=L^{1.275} \cdot L^{0.725}=L^{2}$.

The new methodology of adopting and combining muscle girth and stature measurements (by summing their exponents) as covariates has some similarities to the approach proposed by Darveau and co-workers (Darveau et al. 2002). Darveau et al. advocated combining a weighted sum of mass exponents, each estimated from a diverse range of control sites or processes known to contribute to metabolic pathways. However, the lack of geometric similarity of human physiques (Nevill et al. 2004) confirms the dangers of using body-mass power functions to model MR (now 
known to lead to biased and inflated mass exponents). The alternative proposed methodology also recommends summing the exponents of relevant components, but suggests adopting linear dimensions of body size that will more accurately reflect, rather than disguise, the independent muscular development and body size contributions to both MR and in particular $\mathrm{MMR}\left(\mathrm{VO}_{2} \max \right)$.

Interestingly, the above explanation was anticipated nearly 10 years ago by Nevill (1994), who suspected that a disproportionate increase in muscle mass with body size would lead to the inflated body mass exponents $\geq 0.75$ observed when modelling $\dot{\mathrm{V}} \mathrm{O}_{2}$ max. Unfortunately, this explanation was not based on empirical evidence, but rather on the observations of Alexander et al. (1981), who reported that within a variety of species from the shrew Sorex to the elephant Loxodonta, larger mammals have a greater proportion of proximal leg muscle mass in relation to their body mass, $m^{1.1}$. Nevertheless, Nevill (1994) did suggest introducing stature as well as body mass as predictor variables in an attempt to separate the contributions of body mass from the disproportionate increase in muscle mass within the group. The model adopted in the present study also incorporated stature as an independent measure of body size, but replaces body mass with calf and thigh muscle girths as more sensitive measures of the muscle development identified in the legs.

The present study has highlighted the dangers of fitting body-mass power laws to variables such as basal and maximum metabolic rate, where muscle mass is likely to influence the performance variable to a greater or lesser extent. We recognize that muscle is not the only process that contributes to some of these variables, e.g. metabolic pathways. Nevertheless, by observing the muscular enlargement observed in the Croatian soccer players and also noting a similar muscular enlargement of the arms and legs in other human populations (Nevill et al. 2004) and the proximal leg muscle mass of mammals (Alexander et al. 1981), the present study is able to provide a simple biological explanation for the numerous studies that report inflated mass exponents $b \geq 0.75$ when modelling variables such as maximal metabolic rate $\left(\dot{\mathrm{VO}}_{2} \mathrm{max}\right)$, basal metabolic rate, leg strength and power. We recommend that when modelling such variables, future research should adopt corrected (muscle) girth methodology rather than total mass as the appropriate scaling or normalizing covariate to more accurately reflect and adjust these variables for individuals of different body size.

\section{References}

Alexander, R. M., Jayes, A. S., Maloiy, G. M. O., and Wathuta, E. M., 1981, Allometry of the leg muscles of mammals. Journal of Zoology, 194, 539-552.

Astrand, P.-O., and Rodahl, K., 1986, Textbook of Work Physiology. Physiological Bases of Exercise (London: McGraw-Hill).

Darveau, C. A., Suarez, R. K., Andrews, R. D., and Hochachka, P. W., 2002, Allometric cascade as a unifying principle of body mass effects on metabolism. Nature, 417, 166-170.

DuBors, D., and DuBois, E. F., 1916, Clinical calorimetry. A formula to estimate the approximate surface area if height and weight be known. Archives of Internal Medicine, 17, 863-871.

Hochachкa, P. W., and Somero, G. N., 2002, Biochemical Adaptations-Mechanism and Process in Physiological Evolution (New York: Oxford University Press).

Hoppeler, H., 1990, The different relationship of $\mathrm{VO}_{2} \max$ to muscle mitochondria in humans and quadrupedal animals. Respiration Physiology, 80, 137-146.

Kleiber, M., 1932, Body size and metabolism. Hilgaridia, 6, 315-353.

KLeIBer, M., 1987, The Fire of Life; an Introduction to Animal Energetics (Malabar, Florida: Robert E. Krieger).

McMahon, T., 1973, Size and shape in biology. Elastic criteria impose limits on biological proportions, and consequently on metabolic rates. Science, 174, 1201-1204. 
Nevill, A. M., 1994, The need to scale for differences in body size and mass: an explanation of Kleiber's 0.75 exponent. Journal of Applied Physiology, 77, 2870-2873.

Nevill, A. M., and Holder, R. L., 1994, Modeling maximum oxygen uptake - a case study in non-linear regression model formulation and comparison. Journal of the Royal Statistical Society, Series C, 43, 653-666.

Nevill, A. M., Brown, D., Godfrey, R., Johnson, P. L., Romer, L., Stewart, A. D., and Winter, E. M., 2003, Modeling maximum oxygen uptake of elite endurance athletes. Medicine and Science in Sports and Exercise, 35, 488-494.

Nevill, A. M., Stewart, A. D., Olds, T., and Holder, R., 2004, Are adult physiques geometrically similar?: The dangers of allometric scaling using body mass power laws. American Journal of Physical Anthropology, 124, 177-182.

Schmidt-Nielsen, K., 1984, Scaling: Why Is Animal Size So Important? (Cambridge: Cambridge University Press).

Stewart, A. D., Stewart, A., and Reid, D., 2002, Correcting calf circumference discriminates the incidence of falling but not bone quality by broadband ultrasound attenuation in elderly female subjects. Bone, 31, 195-198.

Weibel, E. R., 2000, Symmorphosis, on Form and Function Shaping Life (Cambridge: Harvard University Press).

Weibel, E. R., 2002, The pitfalls of power laws. Nature, 417, 131-132.

Weiner, J. S., and Lourie, J. A., 1969, Human Biology: a Guide to Field Methods (Oxford: Blackwell Science).

West, G. B., Brown, J. H., and Enquist, B. J., 1999, The fourth dimension of life: fractal geometry and allometric scaling of organisms. Science, 284, 1677-1679.

White, C. R., and Seymour, R. S., 2003, Mammalian basal metabolic rate is proportional to body mass $^{2 / 3}$. Proceedings of the National Academy of Sciences, USA, 100, 4046-4049.

Address for correspondence: Professor Alan M. Nevill, University of Wolverhampton, Research Institute of Health Sciences, Walsall Campus, Gorway Road, Walsall WS1 3BD, UK. email: a.m.nevill (a)wlv.ac.uk

Zusammenfassung. Hintergrund: Die exponentielle Beziehung MR $=a \cdot m^{b}$ zwischen metabolischer Rate $(\mathrm{MR})$ und Körpermasse $(m)$ hat seit vielen Jahren unter Biologen Anlaß zu Unstimmigkeiten gegeben. Verschiedene Studien berichteten, dass der Körpermasse-Exponent $(b)$ größer sei als ein angenommener "Oberflächen-Exponent" von 0.67 , und eher bei 0.75 liege wie ursprünglich von Kleiber festgestellt.

Ziel: Die Studie zielte darauf, eine biologische Erklärung für diesen inflationären "Exponenten" zu bieten und legte die maximale Sauerstoffaufnahme $\left(\dot{\mathrm{V}}_{2} \max \right)$ zugrunde. Sie gründete auf Beobachtungen aus dieser und früheren Studien, dass große Individuen unverhältnismäßig mehr Muskulatur an Armen und Beinen entwickeln.

Versuchsaufbau und Probanden: Es wurde eine Querschnittstudie an 119 18-34-jährigen ProfiFußballspielern aus Kroatien durchgeführt.

Ergebnisse: Wir bestätigen hier, dass die exponentielle Beziehung zwischen $\mathrm{VO}_{2}$ max und Körpermasse bei Profi-Fußballspielern zu einem inflationären Körpermasse-Exponenten von 0.75 (95\% Konfidenzintervall von 0.56 bis 0.93 ) führt, aber auch, dass die größeren Fußballspieler unverhältnismäßig mehr Beinmuskulatur entwickeln. Als die Analyse wiederholt wurde und Waden- und OberschenkelMuskelumfänge anstelle des Körpermasse-Index als unabhängige Variable gewählt wurde, erklärte die Analyse nicht nur einen signifikant größeren Anteil an der Gesamtvarianz von $\dot{\mathrm{VO}}_{2}$ max, sondern es bestätigte die Summe der Exponenten ein Oberfläche-Gesetz.Zusammenfassung: Diese Ergebnisse bestätigen die Schwierigkeiten bei der Anpassung von Exponentialfunktionen an Körpermasse und legen die Muskelumfang-Methode als angemesseneren Weg nahe, metabolische Variablen wie $\mathrm{VO}_{2}$ max für Personen unterschiedlicher Körpergröße zu skalieren oder zu normalisieren.

Résumé. Arrière-plan: La relation de type fonction-puissance RM $=a \cdot m^{b}$, entre le rythme du métabolisme (RM) et la masse corporelle $m$ a longtemps été source de controverses parmi les biologistes. Diverses études ont fait état de coefficients de masse (b) plus élevés que le coefficient 0.67 "d'étendue de surface", initialement proposé par Kleiber et souvent plus proche de 0.75 .

But: A partir d'observations présentes et antérieures montrant que les individus de format plus grand développent relativement plus de masse musculaire dans les membres que les autres, cette étude se propose de fournir une explication biologique de ces coefficients "gonflés" lors de la modélisation de la consommation d'oxygène maximum ( $\left.\dot{\mathrm{VO}}_{2} \max \right)$.

Type de recherche et sujets: Etude transversale de 119 joueurs de football de Croatie âgés de 18 à 34 ans. Résultats: Nous confirmons que la relation de fonction puissance entre la $\left(\dot{\mathrm{VO}}_{2} \max \right)$ et la masse corporelle des joueurs de football professionnels résulte d'un coefficient de masse "gonflé" de 0.75 (intervalle de confiance à $95 \%$ de 0.56 à 0.93 ) et aussi que les sportifs les plus grands présentent une disproportion de la musculature de la jambe et du bras marquées par de plus grandes circonférences. Lorsque l'analyse est répétée après incorporation des circonférences de la jambe et du bras comme variables de prédiction au 
lieu de la masse corporelle, l'analyse explique non seulement une part significativement plus grande de la variance en $\left(\mathrm{V}_{2} \max \right)$, mais aussi, la somme des coefficients confirme l'existence d'une loi "d'étendue de surface"

Conclusions: Ces résultats confirment le piège que constituent les lois de fonction-puissance de la masse corporelle et suggèrent que la méthodologie utilisant les circonférences musculaires est plus appropriée pour quantifier ou normaliser des variables métaboliques telles que $\left(\dot{\mathrm{VO}}_{2} \max \right)$ pour des individus de formats corporels variés.

Resumen. Antecedentes: El exponente $\mathrm{b}$ de la función $\mathrm{MR}=a \cdot m^{b}$, que relaciona la tasa metabólica (MR) y la masa corporal $m$, ha sido el origen de una gran controversia entre los biólogos durante muchos años. Varios estudios han encontrado exponentes de masa $(b)$ mayores que el exponente esperado "superficie-área" 0.67 , estando a menudo más próximos al valor 0.75 identificado originalmente por Kleiber.

Objetivo: El estudio tenía como objetivo proporcionar una explicación biológica para estos exponentes "inflados" cuando se modeliza el consumo máximo de oxígeno ( $\mathrm{V}_{2}$ máx), basándose en las observaciones obtenidas a partir de este y otros estudios previos, en los que los individuos mas grandes desarrollan de forma desproporcionada una mayor masa muscular en brazos y piernas.

Diseño de la investigación y sujetos: Se realizó un estudio transversal en 119 jugadores profesionales de fútbol de Croacia, de entre 18 y 34 años de edad.

Resultados: El estudio confirma que la potencia de la función entre el $\dot{\mathrm{V}}_{2}$ máx y la masa corporal de los jugadores profesionales de fútbol tiene como resultado un exponente de masa "inflado" de 0.75 (intervalo de confianza del $95 \%$ entre 0.56 y 0.93 ), pero también que los jugadores de fútbol de mayor tamaño tienen perímetros musculares de la pierna desproporcionadamente grandes. Cuando se repitió el análisis incorporando los perímetros musculares de la pantorrilla y del muslo como variables predictoras, en vez de la masa corporal, el análisis no solo explicó significativamente mucha más varianza del $\dot{\mathrm{VO}}_{2}$ máx, sino que la suma de los exponentes confirmó una ley superficie-área.

Conclusiones: Estos resultados confirman las dificultades de las leyes de ajuste mediante potencias de la masa corporal y sugieren el uso de la metodología de perímetros musculares, como una forma más apropiada para escalar o normalizar variables metabólicas tales como el $\dot{\mathrm{VO}}_{2}$ máx para individuos con diferentes tamaños corporales. 